\title{
Seed oil chemical composition of Platychaete aucheri (Boiss.) Boiss
}

\author{
Jinous Asgarpanah ${ }^{1,2^{*}}$, Narges Dakhili², Fatemeh Mirzaee ${ }^{2}$, Maedeh Salehi' ${ }^{2}$, Maryam Janipour ${ }^{2}$ and Elaheh Rangriz ${ }^{2}$ \\ YYoung Researchers and Elite Club, Pharmaceutical Sciences Branch, Islamic Azad University, Tehran, Iran. \\ 2Department of Pharmacognosy, Faculty of Pharmacy, Pharmaceutical Sciences Branch, Islamic Azad University, Tehran-Iran (IAUPS).
}

\begin{abstract}
Background: Platychaete aucheri is an endemic plant to the south of Iran and no phyochemical investigations is reported on the seeds oil. Materials and Methods: The chemical composition of Platychaete aucheri seeds oil was extracted by suxhelet apparatus, methyl esterificated and analyzed by GC and GC/MS spectroscopy method. Results: 16 compounds were determined in total and taraxasterol $(19.0 \%), \gamma$-sitosterol $(14.1 \%)$ and lupeol $(11.8 \%)$ were characterized as the most abundant components. Conclusion: Regarding the presence of high amounts of triterpenoids and sterols in the seed oil, related biological activities are expected from the studied oil.
\end{abstract}

Key words: Platychaete aucheri, Asteraceae, Seed oil, Taraxasterol,
gamma-Sitosterol.

\section{Address for Correspondence:}

Dr. Jinous Asgarpanah, Department of Pharmacognosy, Pharmaceutical Sciences Branch (IAUPS), Yakhchal, Shariati, Tehran, Iran.

Phone no: +0098 21 22640051/00989123202988,

Fax no: +982122602059

E-mail: asgarpanah@iaups.ac.ir

DOI : $10.5530 /$ pj.2016.1.9

\section{INTRODUCTION}

The genus Platychaete belongs to Asteraceae family and is represented by five herbaceous perennial species most of which are endemic and grow wild in deserts, wadis and sandy and alluvial habitats of Iran. They are low perennial herbaceous shrub, often cushion shaped and usually up to $60 \mathrm{~cm}$ high and are also found in Afghanistan and Pakistan. ${ }^{1}$ P. aucheri is commonly distributed in South of Iran and is locally called "Kalajook". Fumes from burning are used to treat measles and repel insects. Aerial parts contain essential oil that has a characteristic aroma and is used in traditional medicine as a carminative, antibacterial, antifungal and sedative agent, and as a perfume in handmade soap.

Literature survey revealed that there were just two studies refer to phytochemical investigation of this genus both of which has been done on the clerodanditerpenoids and the essential oil composition of $P$. aucheri aerial parts..$^{2-3}$ Since there was no previous study of $P$. aucheri seed oil, we were prompted to investigate the oil chemical composition of the seeds for the first time.

\section{MATERIAL AND METHODS}

\section{Plant material}

P. aucheri seeds were collected in August 2014 from Najvan Village, Hadji Abad County, Hormozgan Province, Iran: $\left(28^{\circ} \mathrm{c} 18^{\prime} 33^{\prime \prime} \mathrm{N} 55^{\circ} \mathrm{c} 54^{\prime} 06^{\prime \prime} \mathrm{E}\right.$, $1800 \mathrm{~m}$ ). Specimen was identified by R. Asadpour and voucher was deposited in the Herbarium of Pharmaceutical Sciences Branch, Islamic Azad University (IAU), Tehran under code number 5043-AUPF.

\section{Oil extraction}

Oil extraction was performed with a Soxhlet apparatus using n-hexane as the solvent. $100 \mathrm{~g}$ of powdered seeds was extracted for $6 \mathrm{~h}$ and then the solvent was evaporated by using a rotary evaporator at $30^{\circ} \mathrm{C}$. The pure oil was transferred into a small glass vial, flushed with nitrogen and maintained at $-18^{\circ} \mathrm{C}$ until analyzed for fatty acid composition.

\section{Fatty acid methyl esterification}

Fatty acid methyl esters of the extracted oil were prepared according to the method previously reported by Metcalfe et al. $1 \mathrm{~g}$ of the oil was weighed into a volumetric flask. Then, $25 \mathrm{ml}$ of $0.5 \mathrm{~N}$ methanolic potassium hydroxide was added and placed in the boiling water for $20 \mathrm{~min}$. Then $12 \mathrm{ml}$ boron trifluoride $\left(\mathrm{BF}_{3}\right)$ was added and boiled again for 3 min. After that, the flask was cooled and $5 \mathrm{ml} \mathrm{n}$-hexane and adequate saturated $\mathrm{NaCl}$ solution were added. The flask was shaken vigorously and left to stand for $5 \mathrm{~min}$. the fatty acid methyl esters were prepared and dissolved in $\mathrm{n}$-hexane (the upper layer). $2 \mathrm{ml}$ of upper layer was transferred to a small vial and stored at $0^{\circ} \mathrm{C}$ until analyzed by GC/MS.

\section{Analysis of the oil}

Oil sample analysis was performed on a Hp-6890 gas chromatograph (GC) equipped with a FID and a DB-5 capillary column, $30 \mathrm{~m} \times 0.25$ $\mathrm{mm}, 0.25 \mu \mathrm{m}$ film thickness, temperature programmed as follows: $60^{\circ} \mathrm{C}-240^{\circ} \mathrm{C}$ at $4^{\circ} \mathrm{C} / \mathrm{min}$. The carrier gas was $\mathrm{N}_{2}$ at a flow of $2.0 \mathrm{ml} / \mathrm{min}$; injector port and detector temperature were $250^{\circ} \mathrm{C}$ and $300^{\circ} \mathrm{C}$, respectively. Sample was injected by splitting and the split ratio was 1:10.

GC/MS analysis was performed on a Hewlett-packard 6890 /5972 system with a DB- 5 capillary column $(30 \mathrm{~m} \times 0.25 \mathrm{~mm} ; 0.25 \mu \mathrm{m}$ film thickness. The operating conditions were the same conditions as described above but the carrier gas was He. Mass spectra were taken at $70 \mathrm{eV}$. Scan mass range was from $40-400 \mathrm{~m} / \mathrm{z}$ at a sampling rate of $1.0 \mathrm{scan} / \mathrm{s}$. Quantitative data were obtained from the electronic integration of the FID peak areas. The components of the oil was identified by their retention time, retention indices, relative to $\mathrm{C} 9-\mathrm{C} 28 \mathrm{n}$-alkanes, computer matching with the WILEY275.L library and as well as by comparison of their mass spectra with those of authentic samples or with data already available in the literature..$^{5-6}$ The percentage of composition of the identified compounds was computed from the GC peaks areas without any correction factors and was calculated relatively. The analysis of the oil is the average of three replicates for each.

\section{RESULTS AND DISCUSSION}

Table 1 shows the list of compounds whose GC/MS concentration is not less than $0.4 \%$ of total peak concentration. Sixteen components were identified in the oil which presented about $86.6 \%$ of its total composi- 
Table 1:GC-MS analysis of $P$. aucheri seed oil

\begin{tabular}{cccc}
\hline Compound $^{\mathbf{a}}$ & $\mathbf{K}^{\mathbf{b}}$ & $\mathbf{K}^{\mathbf{c}}$ & Percentage \\
\hline $\boldsymbol{n}$-Decane & 996 & 1000 & 1.1 \\
$\boldsymbol{n}$-Dodecane & 1997 & 1200 & 1.0 \\
Hexadecane & 1603 & 1600 & 0.6 \\
Palmitic acid methyl ester & 1980 & 1984 & 0.9 \\
Linoleic acid methyl ester & 2168 & 2173 & 1.1 \\
Octadecane & 1792 & 1800 & 5.7 \\
Nonadecane & 1905 & 1900 & 8.2 \\
Eicosane & 1994 & 2000 & 1.2 \\
Tetracosane & 2306 & 2300 & 8.2 \\
Octacosane & 2807 & 2800 & 5.4 \\
Campesterol & 3299 & 3305 & 3.7 \\
Stigmasterol & 3330 & 3332 & 1.0 \\
$\boldsymbol{\gamma}$-Sitosterol & 3412 & 3408 & 14.1 \\
$\boldsymbol{\beta}$-Amyrin & 3420 & 3424 & 3.6 \\
Taraxasterol & 3443 & 3438 & 19.0 \\
Lupeol & 3492 & 3486 & 11.8 \\
Total & & & 86.6 \\
\hline${ }^{a}$ Compounds listed in order of elution. & &
\end{tabular}

${ }^{\mathrm{a} C o m p o u n d s ~ l i s t e d ~ i n ~ o r d e r ~ o f ~ e l u t i o n . ~}$

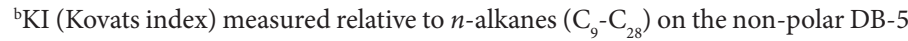
column under condition listed in the Materials and Methods section.

${ }^{c} \mathrm{KI}$, (Kovats index) from literature.

tion. The oil major constituents were found to be taraxasterol (19.0\%), $\gamma$-sitosterol (14.1\%) and lupeol (11.8\%). P. aucheri seed oil comprised four sterols $(37.8 \%)$, two triterpenoids (15.4\%), eight hydrocarbons (31.4\%) and two fatty acids (2.0\%).

The major constitutions of the studied oil were sterols. Sterols are a group of naturally occurring substances derived from hydroxylated polycyclic isopentenoids. Plant sterols (phytosterols), in particular, are important agricultural products for health and nutrition industries. ${ }^{7}$ They are common components of plant foods especially plant oils, seeds and nuts. ${ }^{8}$ The most common phytosterols are campesterol, sitosterol and stigmasterol. As the results all these three sterols were found in the studied oil. Although they are structurally similar to cholesterol, they have been shown to exert significant unique biochemical effects in both in animals and humans. ${ }^{9}$ The main constitution of the studied oil was taraxasterol with a high amount of $19.0 \%$. It is usually found in the plants belong to the Asteraceae family. The distribution of taraxasterol is not extensive in plants but its biological activity is very interesting. Significant chemo preventive, antioxidant and anti-inflammatory properties of this compound have been shown ${ }^{10}$ so the studied oil could deserve greater attention in the evaluation of these kinds of activities.

According to the Table 1, lupeol was characterized as the other major component of $P$. aucheri seed oil. Lupeol is a pharmacologically active triterpenoid. It has several potential medicinal properties. Anti-protozoal, anti-microbial, anti-inflammatory, anti-tumor and chemo preventive properties ${ }^{11}$ have been reported from this compound. Animal models suggest lupeol may act as an anti-inflammatory agent. Lupeol found to decrease paw swelling in rats by $39 \%$, compared to $35 \%$ for the standardized control compound indomethacin. ${ }^{12}$ It is also an effective inhibitor of prostate and skin cancers. ${ }^{13-14}$

Due to the presence of bioactive sterols and the triterpenoid lupeol as the seed oil major components, future studies on the biological and pharmacological properties of $P$. aucheri seed oil are suggested.

\section{ACKNOWLEDGMENTS}

Support from the Pharmaceutical Sciences Branch, Islamic Azad University (IAUPS) is gratefully acknowledged.

\section{ABBREVIATION USED}

GC-MS: Gas Chromatography-Mass Spectrometry.

\section{REFERENCES}

1. Mozaffarian V. A Dictionary of Iranian Plants Name. Farhang Moaser Press, Tehran, Iran; 2006.

2. Javidnia K, Miri R, Nasiri A, Zand F, Soltanipoor M. Essential oil composition of Platychaete aucheri from Iran. Chem Nat Comps. 2008; 44(1): 114-5.

3. Rustaiyan A, Habibi Z, Zderob C. Clerodane derivatives from Platychaete aucheri Phytochem. 1990; 29(3): 985-7.

4. Metcalfe LD, Schmitz AA, Pelka JR. Rapid preparation of fatty acid esters from lipids for gas chromatographic analysis. Anal Chem. 1966; 38(3): 514-5.

5. Swigar AA, Silverstein RM. Monoterpenes. WI: Aldrich Chemical Company Publ. Milwaukee, USA; 1981.

6. Adams RP. Identification of Essential Oil Components by Gas Chromatography/ Mass Spectroscopy. Allured Publishing Co., Carol Stream, IL; 1995.

7. Abidi SL. Chromatographic analysis of plant sterols in foods and vegetable oils. J Chromatogr A. 2001; 935(1): 173-201.

8. Choi YH, Kong KR, Kim YA, Jung KO, Kil JH. Induction of Bax and activation of caspases during $\beta$-sitosterol mediated apoptosis in human colon cancer cells. Int J Oncol. 2003; 23(6): 1657-62.

9. Awad ABM, Schunemann H, Fink CS, Hovey K. A plant food-based diet modifies the serum $\beta$-sitosterol concentration in hyperandrogenic postmenopausal women. J Nutr. 2003; 133(12): 4252-5.

10. Ovesna Z, Vachalkova A, Horvathova K. Taraxasterol and $\beta$-sitosterol: new naturally compounds with chemoprotective/chemopreventive effects. Neoplasma. 2004; 51(6): 407-14

11. Margareth BC, Sarachine GMJ. Biological activities of Lupeol. Int J Biomed Pharm Sci. 2009; 3(1): 46-66.

12. Geetha T, Varalakshmi P. Anti-inflammatory activity of lupeol and lupeollinoleate in rats. J Ethnopharmacol. 2001; 76(1): 77-80.

13. Nigam N, Prasad S, Shukla Y. Preventive effects of lupeol on DMBA induced DNA alkylation damage in mouse skin. Food Chem Toxicol. 2007; 45(11): 2331-5.

14. Saleem M, Afaq F, Adhami VM, Mukhtar H. Lupeol modulates NF-kappaB and PI3K/Akt pathways and inhibits skin cancer in CD-1 mice. Oncogen. 2004; 23(30): 5203-14.

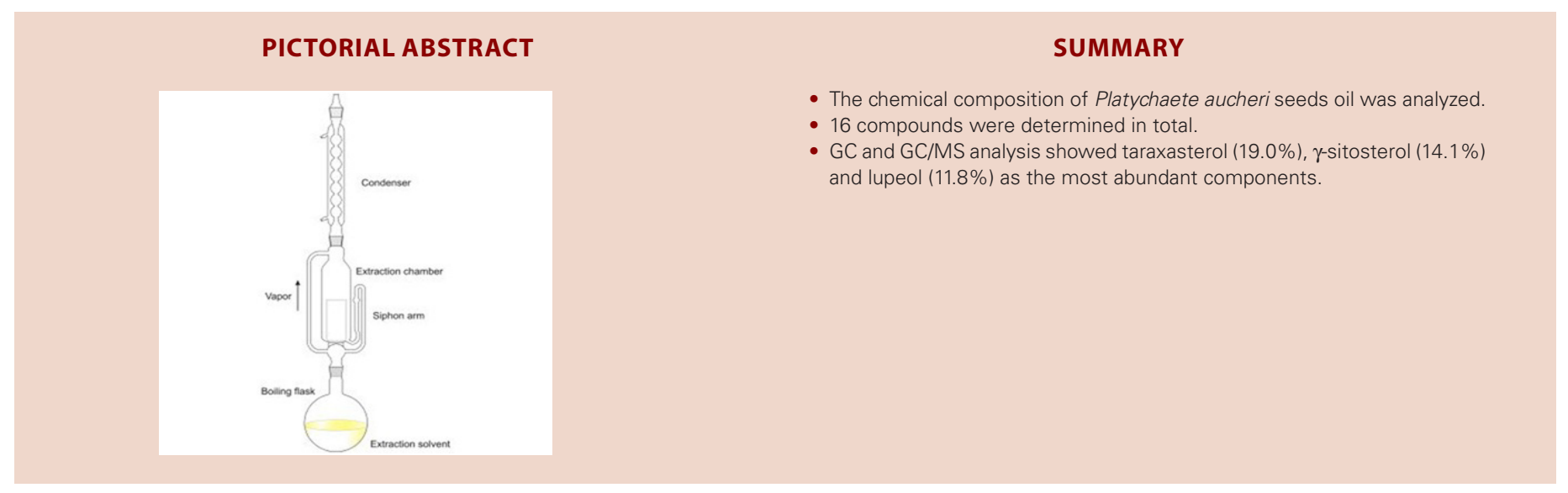

